\title{
LINGUOCULTURAL BASES OF SOCIALIZATION OF FOREIGN APPLICANTS OF HIGHER EDUCATION IN THE UNIVERSITY EDUCATION AREA
}

\author{
Ushakova N., Doctor of Pedagogics \\ Domnich S., Ph.D. in Philosophy \\ Kushnir I., Ph.D. in Pedagogics \\ Trostynska O., Ph.D. in Philology (Kharkiv)
}

The article highlights the problems of the linguocultural socialization of foreign applicantsfor highereducation. The scientific and methodical bases of linguocultural educational system of educational migrants' support that forms in two ways: language training and social and cultural adaptation implemented as per level degree (bachelor's degree, master's degree, Ph.D. degree) were defined according to the tasks of socialization of foreigners in the higher education area. The article describes the potential of the language instruction that plays the role of educational discipline and the basis for the socialization of applicants for higher education in a foreign language and social and cultural environment. The process of linguocultural competence formation among different categories of educational migrants is outlined. The functions of the socially educational process at the university as the main factor of socialization of foreigners were determined. The authors point out that the socialization of foreign students in the educational and cultural environment of higher education institutions (HEIs) should be considered in conjunction with three aspects: linguosocial adaptation, integration, and individualization. Scientific and methodical bases of each of the mentioned aspects were discussed. The main forms of social and pedagogical support of socially educational work with foreign applicants of higher education, who study at V.N. Karazin Kharkiv National University (training courses, cultural assimilators, excursions, local history master classes, theme nights, discussions regarding intercultural communication, creative contests, business games, conferences of young scientists etc.) were specified.

Key words: foreign applicants of higher education, linguocultural socialization, language of education, higher education institution area.

Ушакова Н.I., Домніч С.П., Кушнір І.М., Тростинська О.М. Лінгвокультурологічні основи соціалізації іноземних здобувачів вищої освіти в університетському освітньому просторі. Стаття присвячена проблемам лінгвокультурної соціалізації іноземних здобувачів вищої освіти. Відповідно до завдань соціалізації іноземців в університетському освітньому просторі визначено науково-методичні основи проектування лінгвокультурної освітньої системи підтримки освітніх мігрантів, що формується у двох основних напрямах: мовної підготовки та соціокультурної адаптації, які реалізуються відповідно до освітніх рівнів (бакалаврського, магістерського, рівня докторів філософії). Схарактеризовано потенціал мови навчання, що відіграє роль освітньої дисципліни, підгрунтя соціалізації здобувачів вищої освіти в нерідному мовному та соціокультурному середовищі, описано процес формування лінгвокультурної

(C) Ushakova N., Domnich S., Kushnir I., Trostynska O. 2019 
компетентності різних категорій освітніх мігрантів. Визначено функції виховного процесу в університеті як важливого фактора соціалізації іноземців. Зазначено, що соціалізацію іноземних студентів в освітньо-культурному середовищі закладів вищої освіти необхідно розглядати в сукупності трьох аспектів: лінгвосоціальної адаптації, інтеграції та індивідуалізації, визначено науково-методичні основи кожного з означених аспектів. Описано основні форми соціально-педагогічної підтримки виховної роботи 3 іноземними здобувачами вищої освіти, що навчаються в Харківському національному університеті імені В.Н. Каразіна (тренінги, культурні асимілятори, екскурсії, краєзнавчі майстер-класи та тематичні вечори, круглі столи із проблем міжкультурної комунікації, творчі конкурси, ділові ігри, конференції молодих науковців тощо).

Ключові слова: іноземні здобувачі вищої освіти, лінгвокультурна соціалізація, мова навчання, університетський освітній простір.

Ушакова Н.И., Домнич С.П., Кушнир И.Н., Тростинская О.Н. Лингвокультурологические основы социализации иностранных соискателей высшего образования в университетском образовательном пространстве. Статья посвщена проблемам лингвокультурной социализации иностранных учащихся вузов. В соответствии с заданиями социализации иностранцев в университетском образовательном пространстве определены научнометодические основы проектирования лингвокультурной образовательной системы поддержки образовательных мигрантов, которая формируется в двух основных направлениях: языковой подготовки и социокультурной адаптации, реализующихся в соответствии с образовательными уровнями (бакалаврским, магистерским, доктора философии). Охарактеризован потенциал языка обучения, который играет роль образовательной дисциплины, основу социализации соискателей высшего образования в неродной языковой и социокультурной среде, описан процесс формирования лингвокультурной компетентности разных категорий образовательных мигрантов. Определены функции образовательного процесса в университете как важного фактора социализации иностранцев. Подчеркивается, что социализацию иностранных студентов в образовательнокультурной среде учреждений высшего образования необходимо рассматривать в единстве трех аспектов: лингвосоциальной адаптации, интеграции и индивидуализации, определены научно-методические основы каждого из аспектов. Описаны основные формы социально-педагогической поддержки воспитательной работы с иностранными соискателями высшего образования, обучающимися в Харьковском национальном университете имени В.Н. Каразина (тренинги, культурные ассимиляторы, экскурсии, страноведческие мастер-классы и тематические вечера, круглые столы по проблемам межкультурной коммуникации, творческие конкурсы, деловые игры, конференции молодых ученых).

Ключевые слова: иностранные соискатели высшего образования, лингвокультурная социализация, университетское образовательное пространство, язык обучения.

Problem statement. The current state of development of the university education system is characterized by an awareness of 
tremendous changes in social life, the transformation of the structure of the world information space. At the present stage of the existence of civilization, one of the most important leverages of its development is the educational system, in particular, the training of experts of higher qualification, which main focus is on universities. Globalization of the social life influences the tasks, tendencies, directions of improvement of educational systems. The development of international education, study abroad, intensification of academic exchanges, the interaction of scholars and teachers in the field of development of methods for socialization of non-native speakers in a foreign linguistic environment is one of these directions, the response to today's needs. Such interaction requires the development of a universal terminological system for defining the learning objectives, levels, stages, means of controlling the level of study, etc. The introduction of the European Credit Transfer and Accumulation System (ECTS), the determination of levels of proficiency in foreign languages provided the organizational basis for the implementation of international cooperation in the higher education system. Ukrainian universities follow the current trends that make them adequate participants of the world educational process. V.N. Karazin Kharkiv National University is one of the leading higher educational institutions (HEIs) in Ukraine and a leader in the field of training of foreign specialists of higher qualification. The need for analysis and systematization of scientific and methodical and linguocultural bases of educational migrants' socialization in the higher education area determines the relevance of the research.

Analysis of current researches. At the present stage of human development, the optimization of international education, particularly by the means of a medium of instruction is one of the important tasks. Young people are increasingly looking for the opportunity to study abroad that requires not only mastering the medium of instruction but also the concepts of a new social and cultural environment.

White Paper on Intercultural Dialogue "Living Together As Equals in Dignity" [4] states that the university is ideally suited for the development of open-mindedness and openness to the world, founded on enlightenment values by its universality. The university thus has great potential to engender "intercultural intellectuals" who can play an active role in the public sphere. 
One of the best classical Ukrainian universities, the V.N. Karazin Kharkiv National University is a current member of the International Association of Universities (IAU)/UNESCO, a worldwide association consisting of more than 150 member countries. In 1988, the University signed the Magna Charta Universitatum, a document reflecting the fundamental values and rights of European universities, institutional autonomy, and academic freedom. Since 1989 V.N. Karazin Kharkiv National University has been a co-founder and a member of the Eurasian Universities Association, uniting universities in the Eurasian region on a voluntary basis. In 2004, Kharkiv National University became a full individual member of the European Universities Association. In 2010, the University was admitted to the European Nuclear Education Network (ENEN) as an associate member [7].

Foreigners study at 20 schools: the School of Biology; the School of Geology, Geography, Recreation and Tourism; the School of Ecology; the School of Economics; the School of Foreign Languages; the School of History; the School of Computer Sciences; the School of Medicine; the School of Mathematics and Computer Sciences; the School of International Economic Relations and Travel Business; the School of Psychology; the School of Radiophysics, Biomedical Electronics and Computer Systems; the School of Sociology; the School of Physics and Energy; the School of Physical and Technologies; the School of Physics; the School of Philology; the School of Philosophy; the School of Chemistry; the School of Law, and also at the educational-scientific institute "Karazin Business School". The training of experts of higher qualification covers the whole spectrum of modern classical university education [24].

Linguocultural bases of socialization of foreign applicants of higher education are studied by specialists in various fields of science. The content of cognitive activity and psychological characteristics of the learning process are found out in the works of V. Artemov, B. Bieliaiev, L. Vygotsky, P. Galperin, T. Dridze, M. Zhynkin, I. Zymnya. The methods of mastering language by educational migrants have been analyzed by Z. Klychnikova, O. Leontiev, B. Lomov, N. Ushakova, S. Folomkina.

Successful study of foreigners is possible under the conditions of mastering skills and competencies of speech activity in language instruction, especially in the educational and professional sphere of 
communication, the formation of skills to improve the activities for mastering language and its usage. Language is equally important in the social and cultural socialization of non-native speakers in a foreign linguistic and social and cultural environment. Modern communication in the higher education area is intercultural. The scientifically based organizing of the process includes considering the pattern of the dialogue of cultures (S. Ter-Minasova).

The analysis of scientific research of the problem concerning students' social education at the theoretical and methodological level is highlighted in the works of famous teachers: A. Alexiuk, Y. Babanskyi, V. Bezpalko, P. Pidkasystyi, psychologists: A. Petrovskyi, A. Leontiev, methodists: A. Biliaiev, L. Palamar, S. Domnich, N. Skrypnyk, L. Prokofieva, T. Osypova, I. Bartenieva and others who devoted their works to various forms of extra-curricular activities with students.

The aim of the article is to describe the system of linguocultural socialization of foreign applicants of higher education at the university, for which it is necessary to analyze the bases of language training of educational migrants and to characterize the aspects of socialization of non-native speakers. The tasks of the article are to determine the functions of the language by means of which different categories of foreigners master the future specialty in foreign universities, as well as the characteristics of the intercultural socially educational process at V.N. Karazin Kharkiv National University as a basis of socialization of foreigners in the conditions of foreign social and cultural environment.

Presentation of the main material. Institute of International Education for Study and Research (IIESR) provides linguocultural socialization of foreign nationals at V.N. Karazin Kharkiv National University. The main activities of IIESR are preparation of foreign nationals for getting into Ukrainian HEIs, organization and methodical support for teaching of language courses to foreigners, conducting local history projects for foreign applicants of higher education of all levels, coordination of the schools and departments activities regarding organization of education and training of foreign experts of relevant education and qualification levels, development and implementation of innovative forms and methods of education to ensure adaptation of foreign nationals and stateless persons enrolled in the University. The educational process is based on the principles of science, humanism, democracy [14: 5-6]. 
The training of foreign applicants of higher education is carried out according to educational and professional, educational and scientific and scientific programs at three levels of higher education (bachelor's, master's, and academic and research). European Credit Transfer and Accumulation System (ECTS) was implemented at the University, which draws students into the international university education area, helps to improve the quality of education, enables to integrate different types of educational activities, facilitates the process of recognition and confirmation of qualifications and periods of study, promotes academic mobility of applicants of higher education [15].

Educational migrants, applicants of higher education can study in the state language, national minorities' languages or English, as stated in the contract they conclude. Foreign students are studying in groups with Ukrainian students at most of the schools. Separate academic groups are created and separate curricula are developed at the School of Medicine, the School of Law and "Karazin Business School" for students, who have chosen English language instruction.

According to the Decree of the Ministry of Education and Science of Ukraine of August 18, 2016, No. 997 [12], the University provides state language learning by foreign students to the extent necessary for study and/or everyday communication according to educational programs. In order to ensure the communicative needs of foreign students in Ukrainian-speaking community, the staff of the Institute of International Education for Study and Research solves a wide range of scientific and methodical problems of language training of foreigners, since the formation of communicative competence is a prerequisite for the successful mastering the academic disciplines. Researches, conducted by N. Ushakova, T. Aleksieienko, S. Domnich, I. Kushnir, O. Trostynska allowed to develop the concept of formation of secondary linguistic personality of educational migrants, to build a methodical system of their academic adaptation [1], the central element of which is language training. Educational programs were developed [22] for all foreign higher education applicants of V.N. Karazin Kharkiv National University (School of Foreign Languages, School of Geology and Geography, School of Economics, School of Medicine, School of Radiophysics, School of Law, etc.) Classes on the academic disciplines "Foreign language (Ukrainian)", "Foreign language of professional direction", "Ukrainian for the profession" are held. 
The educational programs of these academic disciplines on Ukrainian as a foreign language are created in accordance with the Draft of Ukrainian Proficiency Standard [18]. Foreign students of both non-philological and philological specialties should master Ukrainian in terms of three credits at least. Students develop "communicative competence at a level sufficient to solve simple communicative issues in the educational and professional sphere of communication. They can perform tasks related to the simple exchange of information on social and cultural or everyday life topics; they can tell about themselves, their loved ones and describe the basic aspects of daily life, using simple sentences. Implementation of the described tasks involves the formation of skills and competences in the main types of speech activity - reading, writing, speaking and listening, in using language tools to realize certain tactics of speech behavior to achieve a communicative goal. The basis of forming the communicative competence is mastering the Ukrainian language system and phonetic, lexical and grammatical skills [22].

A textbook takes the central stage in the system of learning tools. A Ukrainian language educational complex for different contingents of foreign students, which includes manuals for beginners (introductory course and basic course) [16, 17], a basic textbook for the first-year foreign students of non-philological specialties for whom Ukrainian is the language of instruction [19], and a manual for the formation of communicative skills of professional communication for students of medical specialties [2] solves the problem of linguocultural socialization of non-native speakers.

The development of the linguocultural competence that is essential to meet the real communicative needs of foreign students, to use the Ukrainian language in everyday life and in the academic environment while studying in Ukraine; to form mastering skills and abilities to communicate in the Ukrainian language within current issues and communication situations is carried out at meetings of the Club of lovers of the Ukrainian language and culture.

Both classroom and socially educational work are significant for the formation of communicative competence of educational migrants at the level sufficient for communication, within educational and professional, business, social and political, everyday life, social and cultural spheres of communication. Socially educational work is particularly an 
effective tool for increasing foreign student's motivation in learning the language and culture of international communication.

The purpose of the socially educational work is to deepen and broaden the knowledge obtained in the conditions of the educational process, the formation of creative abilities, scientific interests. Scientists define socially educational work as a process in which the student's upbringing, education, and development are fulfilled. This process does not have a fixed term of completion and consistently proceeds from one stage to another depending on the creation of favorable conditions for student's creative activity, for ensuring their cooperation, which allows forming the need of a person for further creative perception of the world [25]. Scientifically based and skillfully organized student's activity in extra-curricular work is focused on the versatile development of personality, the specificity of which at the present stage is the accumulation of social experience by foreign students and the achievement of a high level of communicative culture, etc. [26].

Socially educational work with foreign students at V.N. Karazin Kharkiv National University is an essential part of the educational process. Language Training Department 1 of the Institute of International Education for Study and Research organizes a number of extra-curricular activities aimed at social and academic adaptation of foreign students at the University. Socialization of foreign students in the educational and cultural environment of HEIs should be considered together with three stages: social adaptation, social integration and social individualization [5]. We believe that the process of socialization does not have clearly defined stages but it is a multidimensional phenomenon that has signs of adaptation, integration, and individualization.

The aspect of social adaptation of foreign students to the new educational and cultural environment of the HEIs is realized for the education of first-year foreign students by conducting conversations, study tours to the schools of the University, the Museum of the University history, the Central Scientific Library of the Kharkiv National University, modern art exhibitions related to the University Yermilov Center and Henryk Siemiradzki Art Gallery, in order to share knowledge not only about the recognition of the University as a center of fundamental science and education, but also as a powerful cultural 
center. The aspect of social adaptation includes "the adaptation of foreign students to the educational process and new social and cultural reality... moreover, it works in the non-traditional for them educational and cultural environment of HEIs, with representatives of which they should communicate" [6: 32]. Extra-curricular activities are aimed at successful social adaptation of foreign students to the educational and cultural environment of the University, development of cross-cultural and social and professional literacy. Summing up, they are an important component of the educational and socially educational process. Training courses on tolerance, cultural assimilators, interactive activities ("Let's get to know", "Freshman's Day"), city tours, writing essays and works ("Why I came to Ukraine", "V.N. Karazin Kharkiv National University as a classical university of Ukraine", "Kharkiv, the city where we live and study"), preparation of reports and presentations about students countries, and their hometowns ("My native town", "My country") are conducted. Foreign students participate in the preparation of reports and presentations about the cultural traditions of Ukraine/traditions of their countries. Literary and art nights are held to strengthen friendship and mutual understanding between foreign students and Ukrainian citizens. One of the component of social adaptation is also "Ceremony of Foreign Citizens' initiation into students", "International Festival of Foreign Students and Citizens of Kharkiv", theatre educational events: "Christmas in Ukraine", "Masliana", "Easter in Ukraine", evening-presentations: "The Wonderful World of Ukrainian Embroidery", "Ukrainian Pysanka", etc.

The aspect of social integration involves the development of the social and professional qualities of educational migrants, the formation of value orientation and intercultural competence. "Foreign students... not only master new knowledge of the social and cultural environment but also try to recreate them" [6:34]. The social-pedagogical support for the socialization of foreign students is performed due to following forms of organizational work: a social-pedagogical training "My Future Profession", aimed at holding of vocational guidance, thematic excursions to the Museum of Nature of the University, cultural outings to the Botanical Garden of Kharkiv National University and the planetarium. Educational migrants willingly participate in thematic lessons and lessons-concerts ("Nature is Poetry of the Soul", "Poetry 
Holiday", "Taras Shevchenko, the Great Ukrainian Poet"). Linguistic Olympiads are held to increase interest in language learning.

Foreign students take part in university-wide events (artistic event that envisaged the most mass performance of Ukraine's spiritual anthem "Prayer for Ukraine", that is a solemn piece of music written in 1885 by a graduate of the University M. Lysenko, (the lyrics by Oleksandr Konyskyi) in the OpenAir format, which was registered as a Ukrainian record (2017).

Aspects of social individualization involve the formation of the professional identity of foreign students, their professional selfrealization begins due to the creation of original projects related to professional activity. The main component is the creative activity of foreign students, the implementation of their own educational and professional, and social and cultural projects. For the purpose of the development of social individualization of foreign students, the International Student Conference "New Scientific Horizons: Achievements, Search" (2017-2019) is held.

For scientific and methodological organization of social and pedagogical support of linguocultural socialization of foreign students during extra-curricular activities, such methods are used: social and pedagogical (analysis of real situations, conversation, demonstration of perspectives, individual and collective projects); diagnostic (questioning, testing); personality development (suggestion, example, clarification, criticism, persuasion); organizing of activities (approval, assignment, display of trust, attention, care, support). Forms of social and pedagogical support for extra-curricular activities with foreign students are training courses, cultural assimilators, excursions, workshops, theme nights, discussions, role-playing games, contests, presentations, business games, conferences, sports competitions, quests, concerts, etc. [6:35]. The use of different methods and forms of social and pedagogical support depends on the stage of its implementation during extra-curricular activities.

The process of social and cultural interaction of representatives of different cultures, carried out through the establishment of various social links at the time of interrelated social actions of communicants, should be aimed at forming not only knowledge of foreign (in our case-Ukrainian) culture and language, skills and abilities of communication in this language, but also at a tolerant, respectful 
attitude to representatives of other ethnic groups, as well as cultivating a culture of cross-national communication in the university educational area in order to avoid potential cultural conflicts.

Intercultural communication is always, above all, "general in nature" (Vladymyrova T.), since language interaction is due to the "force field of culture" (Bibler V.), which should not be overlooked by teachers who work with a foreign audience. Then extra-curricular activities will arouse the interest among foreign students and be cognitive communicative in nature, as well as facilitate the effectiveness of education of a multicultural personality, a future specialist of higher qualification.

Organizational work focuses on understanding the interpersonal discourse of non-native speakers as a synergistic, self-developing and sense-generating open system, which is represented in their communicative behavior.

Conclusions. The analysis of scientific and methodical bases of linguocultural socialization of foreigners who receive higher education in Ukrainian HEIs, carried out on the example of V.N. Karazin Kharkiv National University allows to note that the main aspects of the educational process are those of social adaptation, integration, and individualization, implementation of which takes into account the features of intercultural communication and the tasks of developing the skills of dialogue of cultures, creates favorable conditions for communication and learning of educational migrants in foreign academic and social and cultural environment of the University. These aspects also form the basis of vocational training as the main objective of the linguocultural socialization of educational migrants. The process and means of forming the communicative competence of different categories of educational migrants are described. The medium of instruction plays the role of academic discipline; it is the basis for professional and intercultural development of non-native speakers. The socially educational process in the University is described as the important factor of social and cultural support of educational migrants in the conditions of foreign linguistic, educational and social and cultural environments.

Prospects of further research is to study and develop common and nationally oriented components of language training and linguocultural 
socialization of foreign higher education applicants in the scientific and social and cultural space of the modern university.

\section{LITERATURE}

1. Академическая адаптация образовательных мигрантов в стране обучения: монография/ под ред. Н.И. Ушаковой. Харьков, 2017. $248 \mathrm{c}$.

2. Алексєєнко Т.М., Васецька Л.І., Кушнір І.М. Навчання професійного діалогу: Лікар - хворий. Харків, 2019. 58 с.

3. Бакіров В.С., Ушакова Н.І., Хіжняк Л.М. Міжкультурна комунікація в університеті: історичний досвід і виклики сучасності. Вісник Харківського національного університету імені В.Н. Каразіна. Серія «Сочіологічні дослідження сучасного суспільства: методологія, теорія, методи». Харків, 2017. Вип. 39. С. 286-293.

4. Біла книга 3 міжкультурного діалогу «Жити разом у рівності й гідності». К., 2010. 44 с.

5. Білик О.М. Соціалізація іноземних студентів як педагогічна проблема. Вісник Харківської держ. академії культури: зб. наук. праџь / М-во культури Украӥни, Харків. держ. акад. культури. Харків, 2014. Вип. 43. С. 281-289.

6. Билык Е.Н. Социально-педагогическое сопровождение как средство повышения еффективности социализации иностранных студентов в образовательно-культурной среде высшего учебного заведения Украины. Академическая адаптация образовательных мигрантов в стране обучения: монография/ под ред. Н.И. Ушаковой. Х., 2017. C. 24-38.

7. Відділ міжнародних програм та академічної мобільності. URL: http://www.univer.kharkov.ua/ua/general/structure/international_relations department/international1/international (дата звернення: 11.07.2019).

8. Домнич С.П. К вопросу о внеаудиторной работе в рамках межкультурной коммуникации. Актуальні питання сучасного соціогуманітарного знання: зб. матеріалів V Міжвузів. наук.-практ. семінару (м. Харків, 23 січня 2014 р.). Харків: Нац. аерокосм. ун-т ім. М.С. Жуковського «ХАI», 2014. С. 56-57.

9. Зінченко В.М. Позааудиторна робота - важливий крок до діалогу культур. Всеукрайнський науково-методичний семінар Новітні технології у викладанні мов іноземним студентам. Харків. 2017. C. 103-107.

10. Коваль В.Ю. Система позааудиторної діяльності студентів вищих навчальних закладів. Наукові праџі Донеџького національного технічного університету. Серія: «Педагогіка, психологія, соиіологія». 2009. № 6. C. 19-23. 
11. Міжкультурна комунікація в університетському освітньому просторі: монографія / за ред. Н.І. Ушакової. Х., 2019. 232 с.

12. Наказ МОН № 997 від 18.08.2016 року «Про визнання таким, що втратив чинність, наказу Міністерства освіти і науки України від 04 квітня 2006 року № 260». URL: http://ru.osvita.ua/legislation/Vishya_osvita/52124/ (дата звернення: 15.03.2019).

13. Педагогічний словник / за ред. М.Д. Ярмаченка. К., 2001. 516 с.

14. Положення про Навчально-науковий інститут міжнародної освіти ХНУ імені В.Н. Каразіна. URL: //rishennya-vr29102018-4 pdf.rada.karazin.ua (дата звернення: 15.04.2019).

15. Положення про організацію освітнього процесу в ХНУ імені B.H. Каразіна. URL: //profkom.ua/normativni-dokumenti/polozhennyapro-organizatsiyu-osvitnogo-protsesu-harkivskomu-natsionalnomuuniversiteti-imeni-v-n-karazina/ (дата звернення: 14.04.2019).

16. ПАРАЛЕЛЬ. Українська мова для початківців. Вступний курс: навч. посіб. / Ушакова H.I., Алексєєнко Т.М., Кушнір I.М., Петренко І.П. Харків, 2017. 64 с.

17. ПАРАЛЕЛЬ. Українська мова для початківців. Базовий курс: навч. посіб. / Ушакова H.I., Алексєєнко T.M., Кушнір I.M., Петренко I.П. Харків, 2018. 108 с.

18. Проект. Удосконалений стандарт. Українська мова як іноземна. Рівні загального володіння та діагностика. 2016. URL: https://mon.gov.ua/ua/news/mon-proponuye-do-gromadskogo-obgovorennyaderzhavnij-standart-z-ukrayinskoyi-movi-yak-inozemnoyi (дата звернення: 02.09.2018).

19. Українська мова: підручник для іноземних студентів 1 курсу нефілологічних спеціальностей / уклад.: Ушакова Н. І., Тростинська О.М., Копилова О.В., Алексєєнко Т.М., Кушнір I.М. / за ред. Н.І. Ушакової. Харків, 2017. 188 с.

20. Ушакова Н.И. Направления оптимизации академической адаптации образовательных мигрантов в вузах Украины. Гуманітарні проблеми вищої освіти: зб. наук. праць. Вип. 10. Харків, 2018. С. 87-94.

21. Ушакова Н.И. Учебник по языку обучения для иностранных студентов в русле современной образовательной парадигмы (Теория и практика создания учебника по языку обучения для иностранных студентов вузов Украины): монография. Харьков, 2009. 263 с.

22. Ушакова H.I., Алексєєнко T.M., Кушнір I.M. Робоча програма дисципліни «Українська мова за професійним спрямуванням». Харків: ХНУ імені В.Н. Каразіна, 2018. 11 с. URL: http://wwwcenter.univer.kharkov.ua/lang/ua/anot.php (дата звернення: 02.09.2018). 
23. Ушакова Н.І., Алексєєнко Т.М. Концепція мовної підготовки іноземних здобувачів вищої медичної освіти (модель 1 - англомовна форма навчання). Викладання мов у вищих навчальних закладах освіти на сучасному етапі. Міжпредметні зв'язки. Харків: ХНУ імені В.Н. Каразіна, 2019. Вип. 34. С. 219-235.

24. Факультети. URL: http://www.univer.kharkov.ua/ua/departments (дата зверенння: 11.07.2019).

25. Donchenko M.V. Professional and pedagogical training of future teachers in extracurricular work in higher educational pedagogical institutions of Ukraine (these cond half of the twentieth century): Extended abstract of candidate's thesis $\mathrm{PhD}$ in Pedagogics: 13.00.01/ Kharkiv State Pedagogical University named after G.S. Skovoroda. Kharkiv, 2004. 22 p.

26. Havryliuk $O$. The organization of extracurricular educational work of formation of communicative culture of future teachers (based on the course "foreign language, professionally directed"). Bulletin of the National Academy of State Border Service of Ukraine. 2013. Is. 2. 83 p.

\section{REFERENCES}

Aleksyeyenko, T.M., Vaseczka, L.I. and Kushnir, I.M. (2019). Navchannya profesijnoho dialogu: Likar - hvoryj [Professional Dialogue Training: Doctor - Patient]. Kharkiv [in Ukrainian].

Bakirov, V.S., Ushakova, N.I. and Hizhnyak, L.M. (2017). Mizhkulturna komunikacija $\mathrm{v}$ universyteti: istorychnyj dosvid i vyklyky suchasnosti [Intercultural communication at the university: historical experience and challenges of the present]. Visnyk Harkivskoho nacionalnogo universytetu imeni V.N. Karasina. Seriya "Sociolohichni doslidzhennya suchasnoho suspilstva: metodolohiya, teoriya, metody" ["Bulletin of the V.N. Karazin Kharkiv National University. Series "Sociological Studies of Modern Society: methodology, theory, methods”]. Kharkiv, 39, pp. 286-293 [in Ukrainian].

Bila knyha z mizhkulturnoho dialohu "Zhyty razom u rivnosti y hidnosti" [White Paper on Intercultural Dialogue "Living Together As Equals in Dignity"]. (2010). Kyiv [in Ukrainian].

Bilyk, O.M.(2014). Socializaciya inozemnykh studentiv yak pedahohichna problema [Socialization of foreign students as a pedagogical problem]. Visnyk Harkivskoyi derzhavnoyi academiyi kultury [Bulletin of Kharkiv State Academy of Culture]. Kharkiv, 43, pp. 281-289 [in Ukrainian].

Bilyk, E.N. (2017). Socialno-pedagogicheskoe soprovozhdenie kak sredstvo povyshenija effektivnosti socializacii inostrannyh studentov $\mathrm{v}$ obrazovatelno-kulturnoj srede vysshego uchebnogo zavedenija Ukrainy 
[Social and pedagogical support as a tool of increasing the effectiveness of socialization of foreign students in the educational and cultural environment of higher education in Ukraine]. Academicheskaja adaptacija obrazovatelnyh migrantov $v$ strane obuchenija [Academic adaptation of educational migrants in the country of study]. Ushakova, N.I. (Ed.). Kharkiv, pp. 24-38 [in Russian].

Department of International Programs and Academic Mobility. Available at: http://www.univer.kharkov.ua/ua/general/structure/international_relations department/international1/international [Accessed 11.07.2019] [in Ukrainian].

Domnich, S.P.(2014). $\quad \mathrm{K}$ voprosu o vneauditornoj rabote $\mathrm{v}$ ramkah mezhkulturnoj kommunikacii [On the issue of extra-curricular work in terms of intercultural communication]. Aktualni pytannya suchasnoho sociohumanitarnoho znannya: zbirnyk materialiv $V$ Mizhvuzivskoho naukovo-praktychnoho seminaru [Topical Issues of Contemporary SocioHumanitarian Knowledge: Coll. materials V Interuniversity Research Practice seminar] (Kharkiv, January 23, 2014). Kharkiv, pp. 56-57 [in Ukrainian].

Donchenko, M.V. (2004). Professional and pedagogical training of future teachers in extracurricular work in higher educational pedagogical institutions of Ukraine (the second half of the twentieth century). Extended abstract of candidate's thesis. Kharkiv: State Pedagogical University named after G.S. Skovoroda [in English].

Havrylyuk, O. (2013). The organization of extracurricular educational work of formation of communicative culture of future teachers (based on the course"Professional foreign language"). Bulletin of the National Academy of State Border Service of Ukraine. Is. 2 [in English].

Koval, V.Y. (2009). Systema pozaaudytornoyi diyalnosti studentiv vyshhyh navchalnyh zakladiv [System of extra-curricular activity of students of higher educational institutions]. Naukovi praci Doneczkoho natsionalnoho tehnichnoho universytetu. Seriya: "Pedahohika, psykholohiya, sociolohiya” [Scientific works of Donetsk National Technical University. Series: "Pedagogy, Psychology, Sociology"]. 6, pp. 19-23 [in Ukrainian]. Nakaz MON № 997 vid 18.08.2016 roku "Pro vyznannya takym, shho vtratyv chynnist, nakazu Ministerstva osvity ta nauky Ukrainy vid 04 kvitnya 2006 roku № 260" [Order of the Ministry of Education and Science № 997 of August 18, 2016 "On expiration of the order № 260 of the Ministry of Education and Science of Ukraine of April 04, 2006”]. (2016). Available at: http://ru.osvita.ua/legislation/Vishya_osvita/52124/ [Accessed: 15.03.2019] [in Ukrainian]. 
Polozhennya pro Navchalno-naukovyj instytut mizhnarodnoyi osvity Kharkivskoho Nacionalnoho Universytetu imeni V.N. Karazina [Regulation for the Institute of International Education for Study and Research of V.N. Karazin Kharkiv National University]. (2018). Available at: http://rishennya-vr29102018-4 pdf.rada.karazin.ua [Accessed: 15.04.2019] [in Ukrainian].

Polozhennya pro orhanizatsiyu osvitnoho procesu $v$ Kharkivskomu Nacionalnomu Universyteti imeni V.N. Karasina [Regulation for organization of educational process in V.N. Karazin Kharkiv National University]. Available at: http://profkom.ua/normativnidokumenti/polozhennya-pro-organizatsiyu-osvitnogo-protsesu-harkivskomunatsionalnomu-universiteti-imeni-v-n-karazina/ [Accessed: 14.04.2019] [in Ukrainian].

Proekt. Udoskonalenyj standart. Ukrayinska mova yak inozemna. Rivni zahalnoho volodinnya ta diahnostyka [Project. Enhanced standard. Ukrainian as a foreign language. Levels of general possession and diagnostics]. (2016). Available at: https://mon.gov.ua/ua/news/monproponuye-do-gromadskogo-obgovorennya-derzhavnij-standart-z ukrayinskoyimovi-yak-inozemnoyi [Accessed: 02.09.2018] [in Ukrainian].

Schools. Available at: http://www.univer.kharkov.ua/ua/departments [Accessed: 11.07.2019] [in Ukrainian].

Ushakova, N.I. (Ed.). (2017). Akademicheskaja adaptacija obrazovatelnych mirgantov $v$ strane obuchenija [Academic adaptation of educational migrants in the country of study]. Kharkiv [in Russian].

Ushakova, N.I. (Ed.). (2019). Mizhkulturna komunikaciya $v$ universyteczkomu osvitnomu prostori [Intercultural communicaton in university educational area]. Kharkiv [in Ukrainian].

Ushakova, N.I., Aleksyeyenko, T.M., Kushnir, I.M. and Petrenko, I.P. (2017). PARALEL. Ukrainska mova dlya pochatkivciv. Vstupnyj kurs [Parallel. Ukrainian language for Beginners. Introductory course]. Kharkiv [in Ukrainian].

Ushakova, N.I., Aleksyeyenko, T.M., Kushnir, I.M. and Petrenko, I.P. (2018). PARALEL. Ukrainska mova dlya pochatkivciv. Bazovyj kurs [Parallel. Ukrainian language for Beginners. Basic course]. Kharkiv [in Ukrainian].

Ushakova, N.I. (2009). Uchebnik po jazyku obuchenija dlja inostrannykh studentov $v$ rusle sovremennoj obrazovatelnoj paradigmy (Teorija $i$ praktika sozdanija uchebnika dlja inostrannyh studentov vuzov Ukrainy) [Textbook on the language of education for foreign students in the context of a modern educational paradigm (Theory and practice of creating a 
textbook for foreign students at universities of Ukraine)]. Kharkiv [in Russian].

Ushakova, N.I. (2018). Napravlenija optimizacii akademicheskoj adaptacii obrazovatelnyh migrantov $\mathrm{v}$ vuzah Ukrainy [Ways of optimization of academic adaptation of educational migrants in Ukrainian higher educational institutions]. Humanitarni problem vyshhoyi osvity. [Humanitarian problems of higher education]. Kharkiv, 10, pp. 87-94 [in Russian].

Ushakova, N.I. and Aleksyeyenko, T.M. (2019). Kontsepciya movnoyi pidhotovky inozemnyh zdobuvachiv vyshhoi medychnoyi osvity (model 1 - anglomovna formana vchannya) [The conception of language training of applicants for higher medical education (model 1 - the English-language mode of study)]. Vykladannya mov u vyshhykh navchalnyh zakladakh osvity na suchasnomu etapi. Mizhpredmetni zviazky [Teaching Languages at Higher Institutions]. Kharkiv, 34, pp. 219-235 [in Ukrainian].

Ushakova, N.I., Aleksyeyenko, T.M and Kushnir, I.M. (2018). Robocha prohrama dyscypliny "Ukrayinsk amova za profesiynym spryamuvannyam" [The educational program of the academic discipline "Professional Ukrainian language"]. Kharkiv:V.N. Karazin Kharkiv National University. Available at: http://wwwcenter.univer.kharkov.ua/lang/ua/anot.php [Accessed: 02.09.2018] [in Ukrainian].

Ushakova, N.I., Trostynska, O.M., Kopylova, O.V., Aleksyeyenko, T.M. andKushnir, I.M. (2017). Ukrayinska mova: pidruchnyk dlya inozemnyh studentiv 1 kursu nephilolohichnyh specialnostej [Ukrainian language: textbook for first-year foreign students of non-philological specialities]. Ushakova, N.I. (Ed.). Kharkiv [inUkrainian].

Yarmachenko, M.D. (Ed.). (2001). Pedahohichnyj slovnyk [Pedagogical dictionary]. Kyiv [in Ukrainian].

Zinchenko, V.M. Pozaaudytorna robota - vazhlyvyj krok do dialogu kultur [Extra-curricular work is an important step to the dialogue of cultures]. Available at: elibrary.donnuet.edu.ua/930/1/ЧТЦ-Т3--\%20T.b_.pdf [Accessed: 05.18.2019] [in Ukrainian].

Стаття надійшла до редакиіï: 20.09.2019

Ушакова Наталя Ігорівна, докт. пед. наук, професор, завідувач кафедри мовної підготовки 1 Навчально-наукового інституту міжнародної освіти Харківського національного університету імені В.Н. Каразіна (61022, Харків, майдан Свободи, 4); e-mail: ushakova.khnu@gmail.com; orcid: http://orcid.org/0000-0003-4917-7934. 
Ушакова Наталья Игоревна, докт. пед. наук, профессор, заведующий кафедрой языковой подготовки 1 Учебно-научного института международного образования Харьковского национального университета имени В.Н. Каразина (61022， Харьков， площадь Свободы, 4); e-mail: ushakova.khnu@gmail.com; orcid: http://orcid.org /0000-0003-4917-7934.

Natalia Ushakova, Doctor of Pedagogics, Full Professor, Head of the Language Training Department 1, Institute of International Education for Study and Research, V.N. Karazin Kharkiv National University (61022, Kharkiv, 4 Svoboda Square); e-mail: ushakova.khnu@gmail.com; orcid: http://orcid.org/0000-0003-4917-7934.

Кушнір Ірина Миколаївна, канд. пед. наук, доцент кафедри мовної підготовки 1 Навчально-наукового інституту міжнародної освіти Харківського національного університету імені В.Н. Каразіна (61022, Харків, майдан Свободи, 4); e-mail: irina.kushnir.83@gmail.com; orcid: http://orcid.org/000-0002-4349-9652.

Кушнир Ирина Николаевна, канд. пед. наук, доцент кафедры языковой підготовки 1 Учебно-научного института международного образования Харьковского национального университета имени В.Н. Каразина (61022, Харьков, площадь Свободы, 4); e-mail: irina.kushnir.83@gmail.com; orcid: http://orcid.org/000-0002-4349-9652.

Iryna Kushnir, $\mathrm{PhD}$ in Pedagogics, Associate Professor, Language Training Department 1, Institute of International Education for Study and Research, V.N. Karazin Kharkiv National University (61022, Kharkiv, 4 Svoboda Square); e-mail: irina.kushnir.83@gmail.com; orcid: http://orcid.org/0000002-4349-9652.

Тростинська Оксана Миколаївна, канд. філол. наук, доцент кафедри мовної підготовки 1 Навчально-наукового інституту міжнародної освіти Харківського національного університету імені В.Н. Каразіна (61022, Харків, майдан Свободи, 4); e-mail: okasana@ua.fm, orcid: http://orcid.org/0000-0002-2999-629X.

Тростинская Оксана Николаевна, канд. филол. наук, доцент кафедры языковой подготовки 1 Учебно-научного института международного образования Харьковского национального университета имени В.Н. Каразина (61022, Харьков, площадь Свободы, 4); e-mail: okasana@ua.fm, orcid: http://orcid.org/0000-0002-2999-629X.

Oksana Trostynska, Ph.D in Philology, Associate Professor, Language Training Department 1, Institute of International Education for Study and Research, V.N. Karazin Kharkiv National University (61022, Kharkiv, 4 Svoboda Square); e-mail:okasana@ua.fm; orcid: http://orcid.org/0000-00022999-629X. 
Домніч Світлана Павлівна, канд. філос. наук, старший викладач кафедри мовної підготовки 1 Навчально-наукового інституту міжнародної освіти Харківського національного університету імені В.Н. Каразіна (61022, Харків, майдан Свободи, 4); e-mail: spdom.286@gmail.com; orcid: http://orcid.org/0000-0002-2410-925X. Домнич Светлана Павловна, канд. филос. наук, старший преподаватель кафедры языковой подготовки 1 Учебно-научного института международного образования Харьковского национального университета имени В.Н. Каразина (61022, Харьков, площадь Свободы, 4); e-mail: spdom.286@gmail.com; orcid: http://orcid.org/0000-0002-2410-925X. Svitlana Domnich, Ph.D. in Philosophy, Assistant Professor, Language Training Department 1, Institute of International Education for Study and Research, V.N. Karazin Kharkiv National University (61022, Kharkiv, 4 Svoboda Square); e-mail: spdom.286@gmail.com; orcid: http://orcid.org/0000-0002-2410-925X. 